\title{
Attributes of Star Performers
}

\author{
Khalid Nasir* \\ Shadab Fariduddin
}

\begin{abstract}
A star performer in an organization is a person that exceeds general expectations of performance and becomes a role model in the organization. It is vital for the success of organization that the attributes of the star performer should be clearly known so that they could be consciously nurtured. These attributes change with the business trends. With the dawn of the Knowledge Age, a paradigm shift has taken place in the orientation of the organization, the employee and the Human Resources department of the organization. Old competencies have ceased to produce new required results and reidentification of a new set of attributes has become inevitable. This research highlights the sought-after performance attributes across a wide section of industry. The study concludes that the star performer's attributes have changed, talent-centricity has become the need of time and the role of HR department is evolving from the custodian of records to being the catalyst for results and change.
\end{abstract}

Keywords: Star performer, human resource development, performance attributes, employee performance, organizational performance

\section{Introduction}

\subsection{Background of the Study}

Universally in general and in the newer consumer-based economy of Pakistan in particular, organizations have changed. They have become open to experimentation and empowerment, an unlikely approach in the past. Competitive advantage in any organization today is the employee performance that ensures growth and an ability to thwart potentially disruptive competition. Traditional tool sets of working have evolved into 'Ideation' and diversity is preferred over homogeneity in employees. Jobs demand Value Addition. Monolithic, bureaucratic, centralized and one competency based industrial organizational model has given way to new informational organizational model that embodies agile, empowering, multi competency based and participative style of management. This change has created a demand for a new set of attributes an employee needs to demonstrate. Likewise, from being treated as cost, then as assets and now as human capital, employees have also undergone a change. Employees, today behave like businessmen. Their capital is the competency that they invest in the organization and then expect a healthy return. They demand empowerment, participation in decision making and the space to stretch their imagination. Employees eye for work-life balance and opportunities for quick growth. 'Job hoping' has become a norm to discover

*Khalid Nasir is an MS student at SZABIST Karachi, kaynasir@hotmail.com

Shadab Fariduddin is Lead Consultant at Four Corners Group, shadab@fourcg.com 
breakthrough opportunities. Most of the attributes that once considered a recipe for success have been tainted with new qualities. For instance; 'life long employment' used to be a positive attribute for an employee which has now become a demerit.

Employees now demand personal development. Due to this change, employees demonstrate altogether a different set of attributes that need to be taken in consideration for better performance management. A fundamental shift in the functioning of the Human Resource has also been ushered in by a slew of these changes. The traditional passive role of record procedures have replaced the traditional reference-based induction. The purview of performance management has also changed. With these challenges, the HR Department struggles to find out the changing employee attributes so it could design strategies to retain the talent and facilitate it to become star performer.

\subsection{Problem Statement}

Fluid organizational structure, empowered frontline executives, drive for quality that delights customers, networks of coalitions, outsourcing, business happening at the speed of light, multiple careers in a lifetime, expectations of immediate performance and rewards are some of the new realities of today's business world. These factors impinge upon organizational performance which in turn has created a need to re-define the human performance attributes sought after by today's organizations. The thrust of this research is to revisit the attributes of employees, especially that of "the star performers" in the context of shifting realities of the business world and highlight associated implications for employee-employer relations and the human resources management function.

\subsection{Study Objective}

The major objective of this research is to explore the performance attributes that have taken top precedence with the change in business environment. The study also inquires whether the star performer's attributes are independent of gender and industry and the emerging expectations from the HR function.

\subsection{Significance of the Research}

This research is of immense value for the organization, especially for the Human Resources practitioners. It shows them the facet of changed performance attributes so that they can steer the performance appraisals to retain, motivate and engage the top talent in the organization. The research also sheds light on the learning needs of the employees in the context of attributes required for performance. The findings of this research are also helpful to the academia for the curriculum development and teaching discourse.

\subsection{Research Methodology}

Both primary and secondary sources were consulted during this research. Published 
scholastic material was referred. A list of attributes was developed through literature review and surveying the local industry. The final list of 48 attributes was converted into a questionnaire among other questions and circulated to senior HR professionals of 92 organizations using convenient sampling: The response spread of 48 organizations comprises 35 private and 13 public sector organizations of Karachi.

\subsection{Organization of the Study}

The work is organized with literature review in Section 2 and research findings in Section 3, while conclusion and recommendations are discussed in Section 4.

\section{Literature Review}

Human being in industry, from an expendable to indispensable resource and stigmatized by the approach that human talent is only born, not developed, has come a long way. Once considered as a 'cog in wheel' it has transformed into being the wheel itself, even the engine. Maslow's 'Hierarchy of needs' in the year 1954 shifted the way of looking at the human being as driven by punishment to being intrinsically motivated by rewards (Crainer, 1997). The work of Henry Mintzberg in the year 1973 and Charles Handy in 1989 (Crainer, 1997) further highlighted the importance of human being in an organization. Organizations were mainly used to be a place characterized by strict hierarchal structure with focus on increased wealth for owners as presented by Max Weber (Weymes, 2007). Taylor in 1911 (Crainer, 1997) developed a scientific approach to management through his Time \& Motion study and mentioned that work methods could be improved in response to changes in work conditions. McGregor (2005) however, challenged this approach through Theory- $X$ and stated that people may be motivated by reward or fear of punishment. The other extreme that he described as Theory-Y postulated that people in an organization could be motivated intrinsically by involving them in work of their choice and that they are capable to manage their own behaviors. Thus inspiration is more important than motivation (Weymes, 2007). This approach later led to Theory-Z synthesized by William Ouchi (Crainer, 1997) that proposed lifetime employment, concern for employees with work-balance approach, decisions made through consensus and two-way communication among others. Moving ahead to the year 1980, Dr. Peter Senge (Crainer, 1997) introduced 'systems theory' and declared organization as an open-system having permeability to its supra system; largely the political, economical, social and technological environment. Edwards Deming in 1982 (Crainer, 1997) further supported the philosophy of a participative style of management. Additionally, Peter Drucker (Weymes, 2007) among others supported this concept that helped in the emergence of a definition of high performance organization. This changed perspective was further reinforced in 1992 when Tom Peters (Crainer, 1997) highlighted the new essential skills of curiosity, initiative and exercise of imagination in the organization. Crainer (1997) presented an example of these philosophies in action by mentioning Ricardo Semler, who in Brazil during 1980 successfully restructured his family's company Semco by implementing democratic management practices. The example highlighted that employees now expect care and support from their bosses (Schuitema, 2005) and that the old approach of considering employees as cost has become archaic (Payos et al., 2003). 
Today's organizations have turned into people-focused organizations. Kanter (1983) mentioned that companies with a commitment to human resources were 'significantly higher in long-term profitability and financial growth'. Watson Wyatt (Wyatt 2008) also highlighted that companies with superior human capital practices can create more than double the shareholder value than companies with average human capital practices. In contrast to the past, where less ingenuity was desired, organizations now find tempting to hire employees with entrepreneurial characteristics (Hadzima, 2005). CEOs today also appear to realize that investing in $\mathrm{HR}$ will enable the organization perform better. A global survey (PwC Saratoga, 2008) revealed that $89 \%$ of CEOs agreed that the people agenda is one of their top priorities and $67 \%$ agreed that it is where their time would be best spent. A similar study (IBM, 2008) highlighted that among the nine change drivers discussed with CEOs, 'people skills' got $48 \%$ in terms of importance, an increasing trend from $44 \%$ in 2006. Today's enterprise is the people (Cascio, 2003). Great vision without great people is irrelevant and organizations cannot achieve great things without great people (Collins, 2001). Now organizations are being propelled for sustainable growth by the innovation bring about by their most valuable assets, their employees. MIT Sloan Management Review of 2007 (Wolcott and Lippitz, 2007) for instance mentioned Google where employees are allowed to spend $20 \%$ of their time to promote their ideas to their colleagues and build prototypes. IBM is another case in point (Fortune, 2008) where the sales force with uniforms and face-to-face teaching in 1930s has emerged into a new liberated team of wearing anything from suits to khakis, attending to IBM Global Sales School having trips to Bermuda as reward.

Crainer (1997) quoted Meredith Belbin that today's organization is well aware of the fact that an 'ideal candidate can't be found because he cannot exist'. Kanter (1983) highlighted a set of 'power skills' for employees that are entrepreneurial in approach and change-orientated in their execution. MIT Sloan Management Review of 2007 (Wolcott and Lippitz, 2007) brought to light the recruiting practices at Google where the candidate might go through 20 interviews before the company determines the individual's suitability. Jack Welch emphasized on the importance of searching 'positive energy'; ability to 'energize' others; the courage to make tough yes or no decisions; the ability to get the job done and passion in the candidates (Welch 2005). It boils down to job of HR department to look for such 'trainable' material.

Dave Ulrich et al. (1997) has mentioned five major periods of the evolution of HR function as Mechanistic, Legalistic, Organistic and Strategic spread over the last six decades during which it transformed from a labor-oriented to a strategic function. The fifth era is the Catalytic period that started with 2000 and is a proponent of just-in time workforce, pay for competencies and performance, organizational development as 'king' where employees are enabled to reinvent their jobs and set their own targets. Globally, the Human Resource function has now moved to being a member of senior management and contributing in the strategic decision process (Leskin, 2008). Shari Caudron (2003) mentioned prime functions of today's HR as managing culture, facilitating change, while creating market-driven connectivity. Dave Ulrich et al. (2008) mentioned that HR practitioners should not loose focus of the "Human" side in Human Resource. A PwC Saratoga study (2008) mentioned the human capital drivers as leadership engagement, talent management and learning and innovation; all of which seeks HR attention. Another 
study (IBM 2008) revealed organizations' inability to rapidly develop skills to address current/future business needs. These challenges push the HR function to become the catalyst for change. As companies are changing, so can and should the function of Human Resources (Gayle, 2008).

\subsection{The Scenario in Pakistan}

The role and function of HR department in Pakistan also closely mirrors evolutionary stages mentioned above. It has evolved from being a labor department in the 1960s to personnel administration coupled with finance in 1970-1980s to more developed human resources management in 1990s and finally now evolving to human development and talent management in 2000s (Abbas, 2005). Although a lot of organizations are still shadowed by the carrot and stick approach, carrying an image of a 'policeman' towards employees and in the process of renaming the Personnel Departments as 'Human Resources' (Menezes, 2008), today's HR has largely being transformed from an admin outfit into a conscious, strategic function that is trying to attract, develop and retain people with the right mix of aptitude, attitude and abilities to impact the bottom line of the organization. HR was brought to Pakistan mainly by the multinational companies. A few enlightened Pakistani organizations followed their footsteps and developed HR functions based on concepts borrowed from the West or Japan (Menezes, 2008). However, the early 2000 ushered a phenomenal change that also affected the progression of the HR function in Pakistan. The era witnessed economic restructuring and reforms. Positive changes occurred in key macro indicators of the economy. For instance, GDP grew from $4.2 \%$ to $5.3 \%$, inflation decreased from $5.7 \%$ to $3.3 \%$ and exports increased from US $\$ 7.8$ billion to US\$ 12 billion (Hussain, 2004). Such an economic condition fuelled the business expansion and motivated the organizations to invest manifestly in its HR function to support business growth. The successful restructuring of the State Bank of Pakistan (SBP) worth a special mention where HR was made the corner-stone of the turn around strategy. The 14 steps framework (Hussain, 2003) of HR structural transformation at SBP provided a starting point of HR restructuring in all the banks. Later, SBP-led HR forum was established to support other banks for HR restructuring. This impetus revolutionized HR practices in almost all of the banks in Pakistan and put pressure on their associated institutions to follow them. The HR restructuring trend caught on. The booming Telecommunication industry began to revamp its HR strategies to attract and retain the best of the talent. FMCGs were already in a continuous process of re-inventing themselves to adopt the best of HR practices. These three industrial sectors; banking, telecom and FMCG led the HR banding and competitive practices' campaign to attract, hire and retain the top talent as their success and growth only lies in finding and retaining the star performers. Giant public organizations like Pakistan State Oil, Pakistan Telecommunication Company, Sui Southern Gas Company among others also sensed survival by getting engaged in the change-oriented HR interventions.

All this build up created demand for HR professionals. Universities started to offer HR related degrees like MBA-HR and MPA, and a torrent of HR related courses and trainings was experienced. Leading educational institutions like LUMS, IBA started HR branding by promoting their alumni as 'star performers' working in the corporate sector to signify 
the importance of hiring the 'right' graduates so to have star performers in the organization. To provide further support in the development of HR profession, the Higher Education Commission of Pakistan (HEC) extended local and foreign scholarships for students and supported other faculty development programs that helped the HR professionals to remain at the learning curve. Professional HR forums like Pakistan Society of Human Resource Management (PSHRM) and Human Resource Development Network (HRDN), amongst others, were formed that provided a formal platform for the nurturing of the profession. On the organizational front, the strategic importance of HR function was realized and HR systems were developed and restructured in light of the best practices, both locally and globally. Services of foreign HR consultants were sought by many organizations in this context. Broadening of the concept of performance management took place and organizations started to gladly embrace HR tools like 360-degree feedback, Balanced Scorecard, Competencies' based performance appraisals and HR based ERP solutions. Focus was developed to build employees' skill capacities through continuous learning. Recruiting the best talent and retaining the top performers became the top priority for the organizations. Employees' careers changed from being myopic to telescopic. Salary structures were rationalized. Organizations started to look for ways to break free from traditional HR-Admin function to the transformational HR strategic function. In doing so, many organizations got successful while a lot still found themselves struggling. But the best that happened to all of them was that they were at least able to break the jinx of 'non-HR-ism'. All these changes put the HR function in the limelight as it facilitated change by being a catalyst. It is still in the continuation of the same but in a more matured and cogent manner.

In the present business world of Pakistan, the core competence of organizations now lies in the skills of its employees and how they are continually upgraded to the cuttingedge professional practices. The mantra of command and control is gradually being replaced by a participative management style, lean hierarchy and self-managing teams. One-size-fits-all policies are giving way to innovative HR practices that are more 'humane'. Isolated, cynical, employees are being transformed into connected, motivated, value-driven employee owners (Weymes, 2007). The organizational performance in this scenario is vested in the performance attributes of its employees, more importantly of its top performers. The challenges of globalization, cutting-edge technology, demographic changes, the breathless nature of the competition, political uncertainty, rising cost of production, brain drain, de-connect between the industry need and academia, mergers and exit of multinationals, erosion of national boundaries and influx of competition and replacement of an aging workforce with young talent having maverick mindsets have altered the very nature of business in Pakistan and has created enormous responsibility on the HR practitioners. Although HR function got emerged from adolescence, it is still steps behind in truly achieving its strategic role and to achieve the status where the head of human resources should be at least as important as the CFO (Welch 2005).

\section{Research Findings}

The survey response is spread over 48 organizations comprising 35 private and 13 public sector organizations of Karachi. A total of 13 FMCGs; 11 pharmaceuticals; 5 banking and insurance companies; 2 each of automobile, petroleum/energy and courier 
companies; 1 telecommunication company and 12 Information Technology, media and services sector organizations constituted the response.

A list of 48 attributes was categorized into 3 clusters for better understanding. Personal: All traits those are generally inherent to a person; Operational / Functional: Attributes employee becomes skilled at while on job and Strategic: The outward focused attributes of an employee towards organizations' sustainability.

\section{Research Question- (cluster: 1)}

To have a meaningful interpretation, the responses to research questions of cluster-1 present findings to performance attributes and change drivers to business.

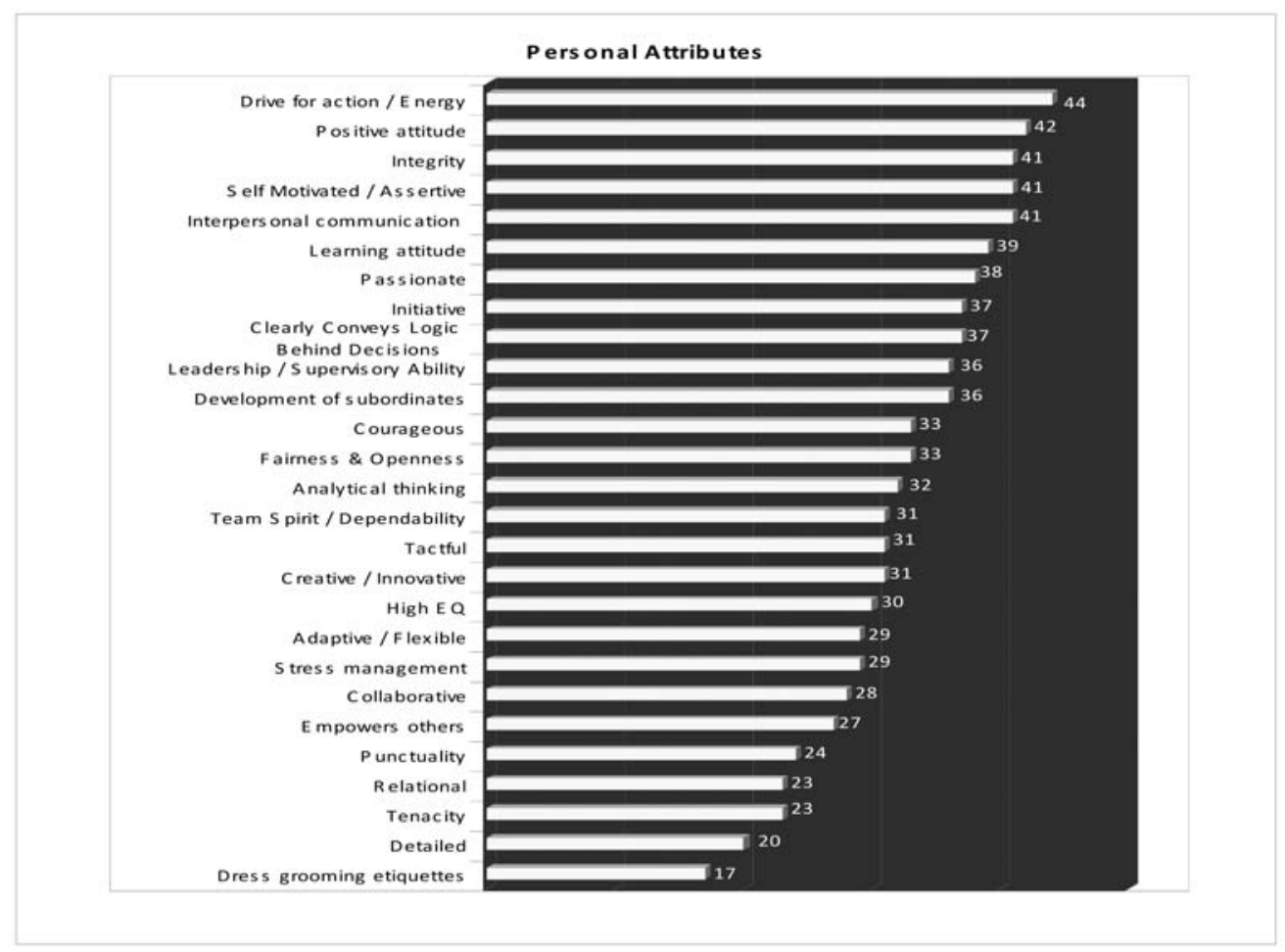

Drive for energy (92\%), positive attitude ( $88 \%)$, integrity ( $85 \%)$, self motivation/ assertion $(85 \%)$ and interpersonal communication $(85 \%)$ came out as top five personal attributes. 


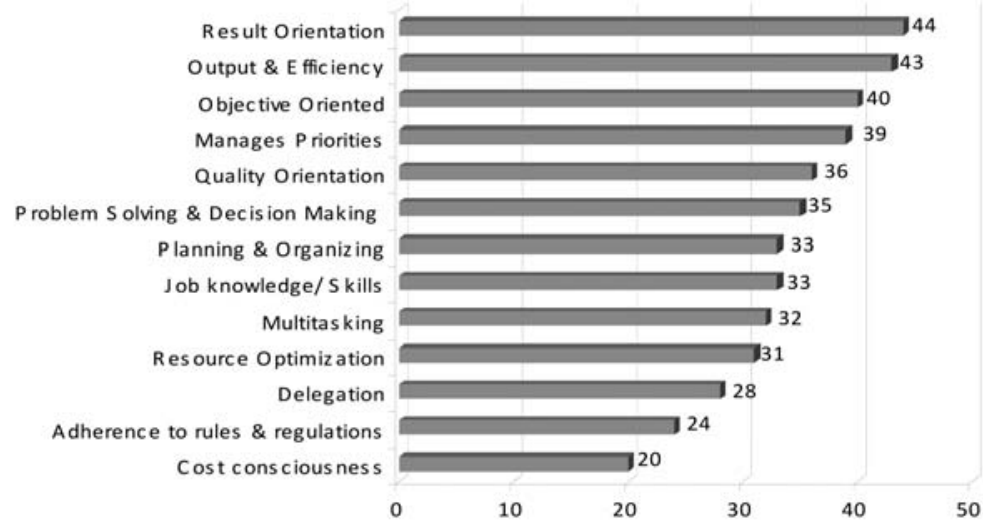

Result orientation (92\%), output and efficiency (90\%), objective oriented ( $83 \%)$, manages priorities $(81 \%)$ quality orientation $(75 \%)$ were marked as top five functional attributes. The attribute 'cost consciousness' was marked at the lowest $(41 \%)$.

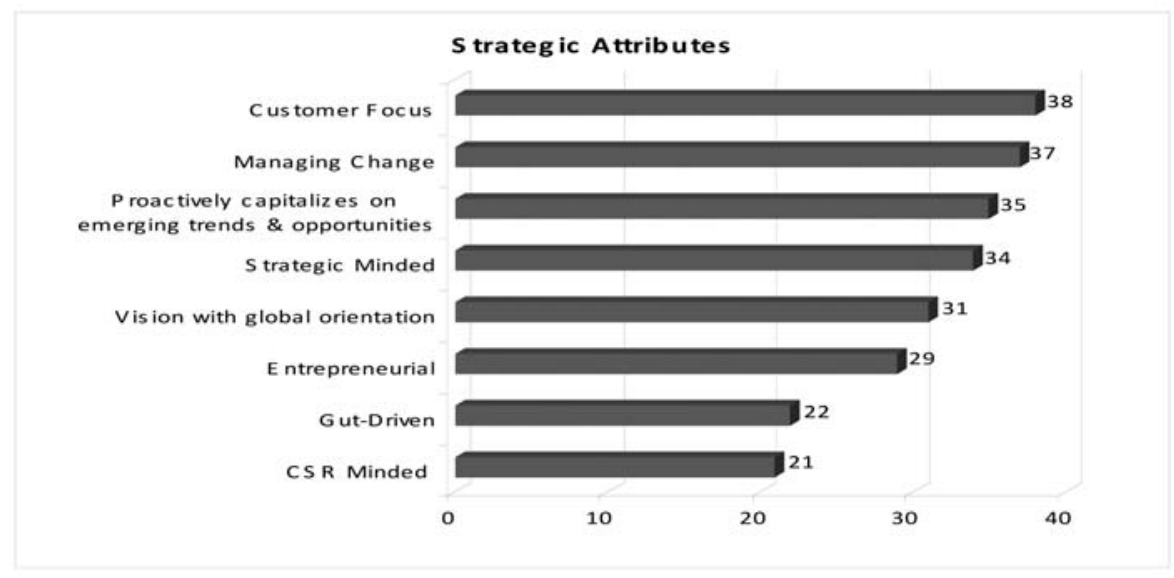

Customer focus $(79 \%)$, managing change $(77 \%)$, proactive capitalization on emerging trends and opportunities $(73 \%)$, strategic mindedness $(73 \%)$ and vision with global orientation $(65 \%)$ came out as top five strategic attributes. The response for 'CSR minded' (43\%) indicates the rising importance of this relatively new performance attribute required in the Pakistani business environment.

Responding to the question of current business challenges faced by organizations, 'Global economic and political uncertainty' (98\%) and 'developing customer / brand loyalty' (81\%) were marked as the significant challenge. Keeping in view the current economic turmoil, respondents also placed 'improvement in operations while cutting on expenses' at an important $75 \%$. 


\section{Research Question - (cluster: 2)}

While highlighting the importance of retaining top performers, a total of 46 respondents $(96 \%)$ were of the opinion that retaining top performers is vital to their organization while 2 respondents $(4 \%)$ disagreed. Those who said "No" did not mention any reasons. Respondents mentioned following vital actions an organization should take to retain top performers: sharing of department and organizational strategies, lateral rotations, market compatible compensation, a separate development plan that aligns their personal aspirations with organizational needs, place them in the high opportunity based tasks, empower and pamper them with freedom of 'doing', provide them an organizational culture that is difficult to find elsewhere and groom bosses to handle top performers.

\section{Research Question - (cluster: 3)}

The responses to research questions of cluster-3 provide answers relating to the attributes being independent of gender and industry. A total of 38 respondents $(79 \%)$ agreed that the performance attributes are independent of gender and industry while 10 respondents $(21 \%)$ disagree. Those who said "NO" highlighted following attributes as being exclusive to female performers: more committed than their male counterparts, thoroughness, better interpersonal communication, delegate more, ability to withstand pressure and empathize in a better way.

\section{Research Question - (cluster: 4)}

The responses to research questions of cluster-4 provide answers relating to the emerging role of Human Resources function in an organization. Responding to the question that "Is the organizations' HR geared up to address to the current business challenges?", a total 35 respondents $(74 \%)$ mentioned that their HR Departments are geared up to address to the current challenges faced while 12 respondents $(26 \%)$ disagree. The major expectations respondents mentioned from HR Department are: development of competitive compensation packages, support entrepreneurship at all levels and allow mistakes to happen, extend learning opportunities, development of a formal reward and recognition program, development of systems that explore unrealized potentials of employees, facilitate two-way communication, ensure that all managers should act like HR managers and guide the top management to retain top performers.

\section{Conclusion and Recommendations}

The study concludes that a new set of performance attributes have taken precedence over others with the changed mindsets of organizations and workforce. For instance, 'life long employment' used to be a prime attribute for a performer but now it is nowhere to be found. Few of the new attributes have also emerged as being important to organizations like 'managing change', 'energy', 'CSR orientation, 'high EQ', 'learning attitude', multitasking', 'entrepreneurial approach', 'development of subordinates' and 'positive attitude' among others. Additionally, top five attributes for top performance selected in each of the category of Personal, Operational / Functional and Strategic have come out in the following manner: 


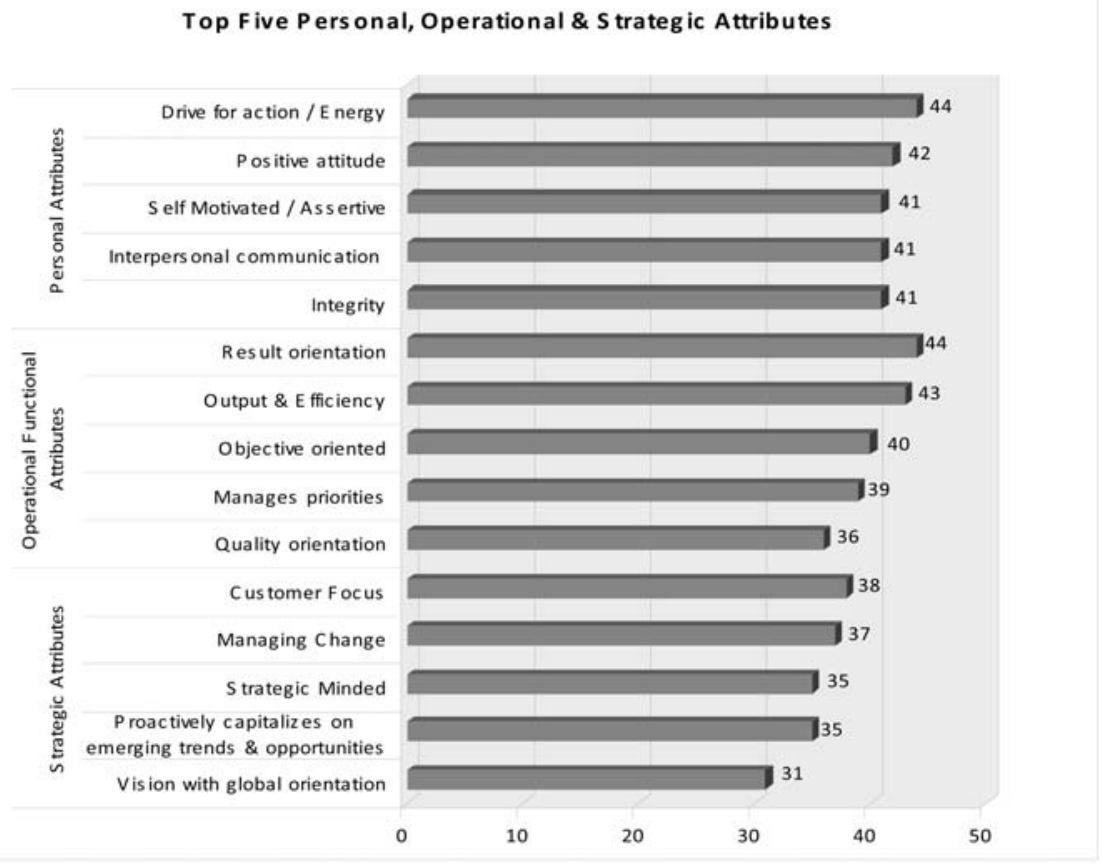

It is very interesting to observe that the business challenges organization faces at present are being addressed by the attributes they crave for in the star performers. For instance, the 'economic and political uncertainty' can be dealt with employees having the attributes of 'managing change', 'global orientation', and 'result orientation'. Likewise, the challenge of creating 'brand loyalty' can be addressed by employees having attributes like 'customer focus', 'drive for action' and 'capitalizing on emerging opportunities'. This connects the highlights that the performance attributes are greatly associated with the shifting business orientation and they change accordingly.

The overall top ten attributes prioritized are as follows:

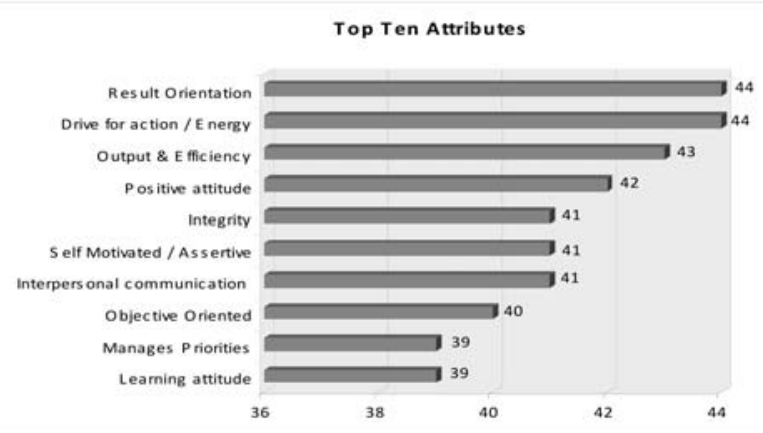

Another interesting finding is the overall bottom ten attributes that are generally given 
precedence over other attributes. For instance, dressing, stress tolerance, adherence to rules and regulations, punctuality among others. However, the research findings reveal that the truth is otherwise. Respondents mark many such attributes as 'low' that shows the descending priority of these attributes. This rating, however, does not dilute their importance for an employee or organization but merely indicates the change in priority that has taken place over a period of time.

Following is the graph that presents the bottom ten attributes:

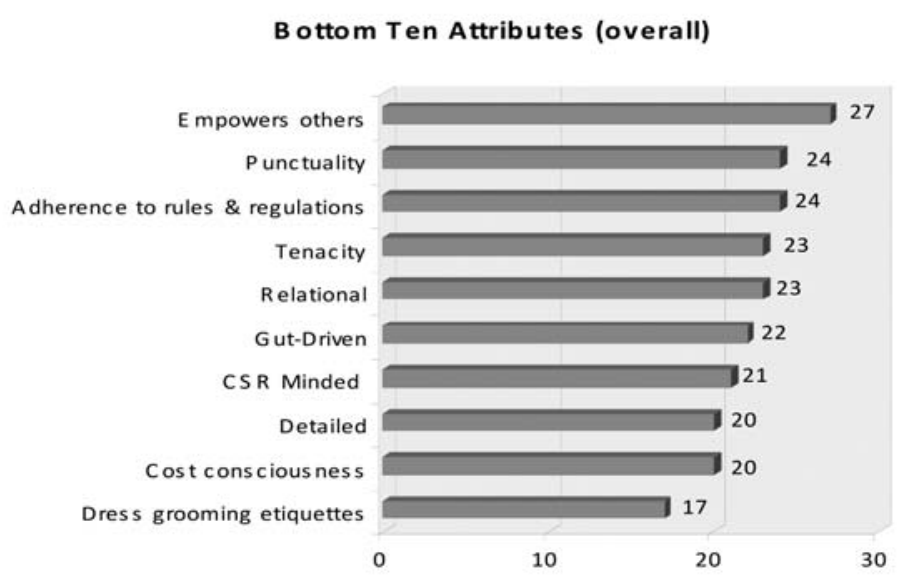

The research also highlights that the majority of organizations are of the opinion that the attributes of top performers are independent of gender which is a very healthy sign and may, in times to come, discourage gender biases. However, further investigations are needed. The study findings present that the performance attributes are independent of the industry. The study also emphasizes on the need of transformation of the HR function in organization to aptly address the challenges it faces today. It clearly indicates that the traditional transactional role of HR is not any more valid to cope with the dynamism of the present day employees and organizations. It also concludes that the HR function should not be undervalued any more; rather it should be consciously and strategically developed to foster an environment that grows star performers. One can imagine the impact on the organizations' performance and bottom line if the majority of employees turned into top performers.

Recommendations for the future areas for research:

1. A time series study that finds out the time frame in which the context, definition and priority of the star performers' attributes change.

2. A study on the attributes of star performers for non-profit and government organizations.

3 A research that explores whether average performers can be changed into star performers? 


\section{References}

1 Abbas, Andleeb, (2005) 'Employer branding for competitive advantage,' Industrial Relations Journal, Employers' Federation of Pakistan, No. 4.

2 Cascio, Wayne F, (2003) Managing Human Resources, New Delhi: Tata McGraw-Hill.

3 Caudron, Shari, (2003) 'What are the Competencies Needed for Next-Generation HR Professionals?' www.workforce.com/archive/feature/23/38/44/233846.php

4 Collins, Jim, (2001) Good to Great. New York: HarperCollins Publishers Inc.

5 Crainer, Stuart, (1997) The Ultimate Business Library, Oxford, Capstone Publishing Limited.

6 Hadzima, Joseph G, (2005) Practical advise for Entrepreneurs, http://web.mit.edu/eclub/hadzima/seven-characteristics-of-highly-effective-entrepreneurialemployees.html

7 Hussain, Ishrat (2004) Economy of Pakistan; Past, Present and Future. www.sbp.org.pk/about/speech/2004/eco_of_pk(past_present_future.pdf

8 Hussain, Ishrat (2003) Human Resource management in practice: A case study of State Bank of Pakistan, www.sbp.org.pk/about/speech/2003/HRM-inPractice(18102003).pdf

9 IBM, (2008) IBM Sales Force, Now and Then, Fortune September, Hong Kong, Time Asia Vol. 158, Number-5, pg. 68

10 IBM, (2008) IBM global human capital study, http://ibm.com/bcs/humancapital, Accessed: 08 September 2008

11 IBM, (2008) IBM global CEO study, http://ibm.com/enterpriseofthefuture

12 Kanter, Rosabeth M, (1983) The Change Masters, New York, Simon \& Schuster.

13 Lantz, Gayle (2006) Your company needs to adapt to the HR's evolution, B irming a m Business Journal, www.bizjournals.com/birmingham/stories/2006/11/20/focus4.html

14 Leskin, Barry (2004) The evolution of HR leaves many businesses behind, San $J o s e \quad B u s i n$ e s s J o u r $n$ a l, www.bizjournals.com/sanjose/stories/2004/08/30/focus2.html 
15 McGregor, Douglas (2005) The human side of enterprise, annotated edition, McGraw-Hill.

16 Menezes, Leon (2008) The changing role of Human Resources, www.pshrm.org/files/kb_showarticle.asp?n=9\&article $=23$

17 Payos, Ranulfo P and Orlando S. Zorilla (2003) Personnel Management in the $21^{\text {st }}$ Century, Philippines, Perfecto S. Sison, pp.198 - 208.

18 PwC, Saratoga (2008), Managing people in a changing world, www.saratogapwc.co.uk

19 Schuitema, Etsko (2005) 'The Care and Growth Leadership Model \& Employee Commitment,' LUMS Business Recorder, Pakistan, Lahore University of Management Sciences, Vol.1, No. 1, pp. 99-100.

20 Ulrich, Dave et al. (1997) Tomorrow's HR Management, New Jersey: John Wiley \& Sons, Inc.

21 Ulrich, Dave et al. (2008) Heed these Strategies, www.workforce.com/ archive/feature/22/15/80/223138.php

22 Welch, Jack, (2005) Winning, New York: Harper Collins publications.

23 Weymes, Ed (2007) A Challenge to Traditional Management Theory, Pakistan Management Review, Pakistan Institute of Management, Vol. XLIV, pp. 87-102.

24 Wolcott, Robert C. and Michael J. Lippitz (2007) The Four Models of Corporate Entrepreneurship, USA, MIT Sloan Management Review, Vol. 49, No.1, pp. 76-82.

25 Wyatt, Watson Worldwide $\mathrm{HCl}$, (2008) Global Truths, www.watsonwyatt.com/research/featured/hci.asp 